\title{
Pengiklanan Tao Silalahi Arts Festival 2018-2019 Melalui Media Sosial Instagram
}

\author{
Mei Linda Br Tarigan \\ Etnomusikologi, Fakultas Ilmu Bahasa, Universitas Sumatra Utara, \\ Jalan Perpustakaan No. 2, Padang Bulan, Kecamatan Medan Baru, \\ Kota Medan, Sumatera Utara-20222 \\ E-mail: meilindatarigan92@gmail.com
}

\begin{abstract}
ABSTRAK
Penelitian ini bertujuan untuk mengidentifikasi bentuk pengiklanan dan mengetahui strategi pengiklanan Tao Silalahi Arts Festival (TSAF) 2018-2019. TSAF merupakan sebuah festival seni budaya yang berlokasi di Silalahi Sumatra Utara. Penelitian ini menggunakan metode kualitatif deskriptif melalui teknik wawancara, observasi, dokumentasi, dan studi pustaka. Bentuk iklan TSAF akan diidentifikasi menggunakan konsep Berkowitz yang membagi bentuk iklan berdasarkan bentuk dan kelembagaan. Sementara strategi pengiklanan TSAF akan diungkap dengan konsep David yang berupa tahapan-tahapan strategi meliputi, perumusan strategi (perencanaan); pelaksanaan strategi; dan evaluasi strategi. Hasil dari penelitian ini menunjukkan (1) bentuk pengiklanan TSAF 2018-2019 melalui Instagram menggunakan bentuk pengiklanan berjenis produk dan institusi. Iklan jenis produk bertipekan perintisan yang digunakan untuk menyampaikan informasi secara mendetail dan penguatan yang digunakan untuk menguatkan hal-hal sebelumnya pernah dilakukan. Sementara iklan berjeniskan kelembagaan bertipekan pembelaan yang digunakan untuk mendudukkan keberpihakan TSAF dalam suatu persoalan dan kelembagaan perintis yang digunakan untuk menginformasikan sesuatu secara rinci akan tetapi lebih mengarah kepada jasa baik. (2) Strategi pengiklanan TSAF 2018-2019 terdiri dari tiga tahap, yaitu berupa perumusan strategi, pelaksanaan strategi, dan evaluasi strategi. Pada tahap perumusan, TSAF memulainya dengan penerjemahan tagline, penentuan pangsa pasar, perumusan program, riset waktu unggah, dan pemanfaatan fitur. Dalam pelaksanaannya, desain TSAF 2018-2019 menggunakan gaya riasan tidak seimbang sebagai penataan yang seimbang tetapi tidak simetris. Program pemberian hadiah dan promosi, kerja sama dengan influencer, dan kampanye isu lingkungan dapat terlaksana dengan respons yang baik. Pemanfaatan fitur seperti hashtag (\#), caption, lokasi, dan mention sudah difungsikan dengan tepat. Berdasarkan evaluasi yang dilakukan, strategi pengiklanan TSAF 2018-2019 dapat dikatakan berhasil dengan adanya peningkatan pengunjung, akan tetapi perlu adanya upaya untuk menyinergikan antara persiapan yang direncanakan dengan pelaksanaannya.
\end{abstract}

Kata kunci: bentuk, instagram, pengiklanan, strategi, tao silalahi arts festival

\section{Advertising of Tao Silalahi Arts Festival 2018-2019 \\ Through Instagram Social Media \\ ABSTRACT}

This study aims to identify the form of advertising and determine the advertising strategy of the Tao Silalahi Arts Festival 2018-2019 (TSAF). TSAF is a cultural arts festival located in Silalahi North Sumatra. This research uses descriptive qualitative methods through interview techniques, observation, documentation, and literature study. The form of TSAF advertisement will be identified using the Berkowitz concept which divides the form of advertising based on form and institutional. While the TSAF advertising strategy will reveal the concept David' in the form of strategic stages including strategy formulation (planning); strategy implementation; and strategy 
evaluation. The results of this study show (1) the form of advertising for TSAF 20182019 through Instagram using the form of advertising for various types of products and institutions. Advertising of product types pioneering that are used to provide detailed information and reminders that are used to reinforce things that have been previously done. Meanwhile, type advertisement institutional with type is advocacy used to show the alignment of TSAF in an issue and institutional pioneering is used to inform something in detail but leads to good service. (2) The 2018-2019 TSAF advertising strategy consists of three stages, namely in the form of strategy formulation, strategy implementation, and strategy evaluation. At the formulation stage, TSAF started with translating the tagline, determining market share, formulating programs, researching upload times, and utilizing features. In the implementation, the 2018-2019 TSAF design uses the unbalance make-up style as a balanced but not symmetrical arrangement program away and promotion, cooperation with Giving influencers, and campaigns on environmental issues can be carried out with good responses. The use of features such as hashtag (\#), caption, location, and mention has been used correctly. Based on the evaluation carried out, the 2018-2019 TSAF advertising strategy can be said to be successful with an increase in visitors, but there is a need for efforts to synergize the planned preparation with its implementation.

Keywords: form, instagram, advertising, strategy, tao silalahi arts festival

\section{PENDAHULUAN}

Indonesia sebagai sebuah destinasi kepulauan memiliki kekayaan potensi sumber daya wisata alam, budaya serta buatan yang membentang di seluruh wilayah kepulauan Indonesia. Kekayaan dan keunikan sumber daya wisata tersebut memberikan berbagai atribut penting dan strategis bagi Indonesia dalam mengembangkan potensinya, selain juga menjadi modal dasar yang vital bagi Indonesia dalam mengembangkan produk wisatanya agar menjadi salah satu destinasi pilihan bagi pasar wisatawan Indonesia serta wisatawan dari berbagai kawasan di dunia. Salah satu objek wisata alam yang unik yang ada di Indonesia terdapat di Kecamatan Silahisabungan, Kabupaten Dairi Provinsi Sumatra Utara. Kecamatan Silahisabungan memiliki objek wisata dengan alam yang mempunyai kontur perbukitan, alam yang asri dan sejuk, hamparan danau yang luas serta keanekaragaman peristiwa alam yang membentuk keindahan untuk dikagumi. Ke semuanya itu merupakan modal sumber daya yang besar yang berguna bagi usaha pengembangan dan peningkatan kepariwisataan Indonesia yang secara umum bertujuan untuk meningkatkan kesejahteraan masyarakat.

Sebagai salah satu sektor yang berperan cukup signifikan guna membantu meningkatkan penerimaan pendapatan asli daerah dan daya beli masyarakat sekitar objek wisata, sumber daya wisata di Kecamatan Silahisabungan Kabupaten Dairi perlu dikelola dengan baik dan dipromosikan secara terusmenerus agar dapat berkembang dari waktu ke waktu. Hal tersebut telah terwujud dengan adanya kegiatan Tao Silalahi Arts Festival (TSAF) yang terselenggara setiap tahunnya. TSAF merupakan usaha Rumah Karya Indonesia bersama masyarakat setempat untuk mengangkat budaya serta memperkenalkan 
Kecamatan Silahisabungan dengan potensi-potensi yang menarik untuk dikunjungi sebagai daerah pariwisata sekaligus promosi Geopark Kaldera Toba kepada publik. Perpaduan atraksi budaya dalam Tao Silalahi Arts Festival dengan kekayaan potensi wisata Danau Toba sangat luar biasa, dan dengan menguatnya objek wisata seperti ini potensi Danau Toba semakin meningkat, terutama karena kegiatan tersebut juga melibatkan masyarakat sekaligus untuk melestarikan alam.

TSAF pertama kali dilaksanakan pada tahun 2016 dengan tajuk Silalahisabungan Arts Festival (SAFE \#1), dan kegiatan ini mendukung lokasi Pulau Paropo atau Pulau Situngkir menjadi daerah perkemahan. Pada tahun 2017 berlanjut dengan kegiatan SAFE \#2 yang dihadiri ribuan pengunjung. Pada tahun pertama dan kedua, festival ini memakai nama Silahisabungan Arts Festival. Pada tahun ketiga, yaitu 2018, berubah nama menjadi Tao Silalahi Arts Festival karena Tao Silalahi dipandang mampu membawa aura positif dari segi penamaan, lebih mengangkat daerah dan kultural. Tao Silalahi Arts Festival (TSAF) merupakan program seribu tenda yang pertama sukses menggabungkan daerah perkemahan dipadukan dengan panggung budaya yang dihadiri 7.321 orang pengunjung.

Peningkatan peserta dalam Tao Silalahi Arts Festival 2019 mencapai 9.253 peserta, di antaranya: 2.000 masyarakat lokal, 500 seniman dari dalam dan luar Sumatra, pengunjung/peserta perkemahan sebanyak 6.753 peserta. Dari data yang penulis dapatkan, tercatat bahwa setiap tahunnya TSAF mengalami peningkatan pengunjung/peserta. Terlihat dari tahun ke tahun festival ini mengalami peningkatan baik itu masyarakat lokal maupun seniman dari dalam dan luar Sumatra. Terjadinya peningkatan pengunjung dalam sebuah festival dapat disebabkan oleh berbagai faktor. Salah satu di antaranya ialah mengenai pengiklanan yang dilakukan oleh penyelenggara kegiatan. Dalam pelaksanaannya, menurut Andi Siboro selaku tim publikasi TSAF menjelaskan bahwa TSAF hanya melakukakan pengiklanan melalui media sosial seperti Instagram, Facebook, dan Twitter. Akan tetapi di antara media tersebut Instagram menjadi media yang paling masif digunakan.

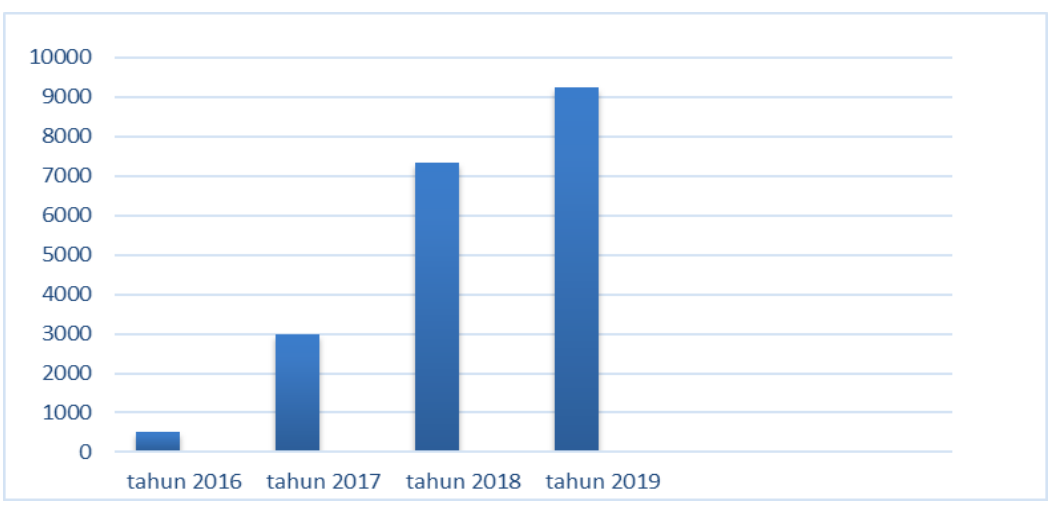

Gambar 1: Diagram 1, Volume Pengunjung Tao Silalahi Arts Festival Tahun 2016-2019 Sumber: Panitia Tao Silalahi Arts Festival 
Media sosial Instagram sendiri digunakan oleh TSAF semenjak tahun 2018. Tahun sebelumnya informasi mengenai TSAF dilakukan melalui media sosial Rumah Karya Indonesia (RKI). Seperti halnya data yang dipaparkan sebelumnya, terjadi peningkatan pengunjung yang cukup signifikan dari tahun 2018 dan 2019. Bahkan kehadiran pengunjung tidak hanya terbatas pada pengunjung lokal, melainkan pengunjung dari luar Sumatra Utara seperti Aceh, Riau, Sumatra Barat, serta turis mancanegara. Media iklan dan promosi saat ini berkembang semakin luas dengan berkembangnya New Media Marketing yang mengacu pada pemanfaatan serangkaian teknik pemasaran modern (berbasis internet) dan penggunaan teknologi informasi yang dinilai lebih efisien tetapi efektif dalam menjangkau segmen pasar yang lebih luas. Model penggunaan media pemasaran ini di antaranya adalah berbagai situs yang menjual secara daring bermacam produk kegiatan pertunjukan, pariwisata, dan jasa pelayanan pendukungnya seperti tiket penerbangan, akomodasi, serta paket wisata.

Media sosial merupakan tempat orang berkomunikasi antarsesama pengguna secara tidak langsung dan dibutuhkan koneksi internet. Pengguna media sosial dapat berbagi informasi berupa kejadian, foto, dan video. Selain itu, para penggunanya juga dapat menambah wawasan dan teman. Pesatnya perkembangan teknologi saat ini menyebabkan banyak aplikasi media sosial baru bermunculan. Pada era ini, dengan mengandalkan ponsel (smartphone) yang terkoneksi dengan internet, kita dapat mengakses Facebook, Twitter, Line, WeChat, Instagram di mana pun dan kapan pun. Banyak masyarakat saat ini mencari berita atau informasi dari internet dan media sosial karena sangat mudah untuk diakses, namun banyak kalangan anak muda yang lebih tertarik aktif di Instagram. Instagram berfokus pada foto dan video diikuti pesan singkat sehingga membuat anak muda lebih tertarik untuk menggunakannya. Lestari (2019, hlm. 11) memaparkan bahwa pengguna Instagram bebas memilih untuk melihat unggahan apa saja yang ada di platform Instagram, baik untuk melihat unggahan yang menginspirasi, mencari informasi, atau untuk berbagi cerita mereka dengan mengunggah foto ataupun video.

Lestari (2019, hlm. 30) menerangkan bahwa Instagram merupakan media sosial dengan jumlah pengguna terbanyak ketujuh di dunia. Instagram merupakan platform jejaring sosial yang digunakan untuk berbagi foto, video, dan juga untuk memasarkan produk bisnis. Diketahui pula jumlah total penguna media sosial ini mencapai angka 800 juta pada bulan Januari 2018. Pengguna aktif Instagram paling banyak berasal dari Amerika Serikat dengan jumlah mencapai 110 juta. Satu peringkat di bawahnya adalah Brazil dengan 57 juta pengguna aktif. Pada peringkat ketiga, ada Indonesia dengan jumlah pengguna aktif 55 juta. Instagram juga merupakan media sosial populer dan paling sering digunakan keempat 
setelah Youtube, Facebook, dan WhatsApp. Instagram begitu populer karena fitur-fiturnya yang unik.

Berdasarkan pemaparan yang telah disebutkan, penulis tertarik untuk menganalisis Pengiklanan Tao Silalahi Arts Festival 2018-2019 melalui Instagram. Tujuan dari penelitian ini ialah untuk mengidentifikasi bentuk dan strategi pengiklanan Tao Silalahi Arts Festival tahun 2018-2019. Iklan merupakan alat utama bagi perusahaan untuk memengaruhi konsumennya agar tertarik dengan barang atau jasa yang ditawarkan, iklan dapat dilakukan oleh pengusaha melalui surat kabar, radio, majalah, televisi, dan poster. Shimp (2003, hlm. 14) mendefinisikan iklan sebagai suatu proses persuasi yang tidak langsung, yang didasari pada informasi tentang kelebihan suatu produk yang disusun sedemikian rupa sehingga menimbulkan rasa menyenangkan yang akan mengubah pikiran orang untuk melakukan tindakan atau pembelian.

Berkowitz (1986, hlm. 459) menyatakan bahwa pada hakikatnya periklanan dapat dilakukakan dengan berbagai tujuan yang berbeda, namun tetap didasari oleh dua tipe subjeknya, yaitu produk dan institusi. Berfokus pada penjualan barang dan jasa, iklan tipe produk terbagi dalam tiga bentuk, yaitu perintisan, persaingan, dan penguatan. Iklan institusional lebih mengutamakan sasarannya pada pemberian jasa baik (goodwill) atau gambaran suatu organisasi, ketimbang mengemukakan barang atau jasa. Iklan digunakan para pengusaha untuk mengemukakan dan membentuk kepercayaan publik terhadap nama perusahaannya. Tiga alternatif iklan institusional, yaitu advocacy, pioneering institutional, dan competitive institutional.

Strategi merupakan alat untuk mencapai tujuan, dalam pengembangannya konsep mengenai strategi harus terus memiliki perkembangan dan setiap orang mempunyai pendapat atau definisi yang berbeda mengenai strategi. David (2011, hlm. 18-19) menerangkan bahwa strategi adalah sarana bersama dengan tujuan jangka panjang yang hendak dicapai. Strategi bisnis mencakup ekspansi geografis, diversifikasi, akusisi, pengembangan produk, penetrasi pasar, pengetatan, divestasi, likuidasi, dan usaha patungan atau joint venture. Strategi adalah aksi potensial yang membutuhkan keputusan manajemen puncak dan sumber daya perusahaan dalam jumlah besar. Jadi, strategi adalah sebuah tindakan aksi atau kegiatan yang dilakukan oleh seseorang atau perusahaan untuk mencapai sasaran atau tujuan yang telah ditetapkan. Menurut David (2011, hlm. 283), tahapan-tahapan strategi terdiri dari tiga tahapan yaitu perumusan strategi, pelaksanaan strategi, dan evaluasi strategi.

Beberapa penelitian yang pernah dilakukan adalah sebagai berikut. Tinjauan pustaka yang yang pertama dalam penelitian ini ialah melalui jurnal Aprilianti Pratiwi dan M. Girindra Madanacaragni (2020) berjudul Instagram sebagai Media Promosi Festival Pariwisata Kota Bogor (Studi Etnografi Virtual padaAkun@Cgmbogor_Fest). Panitia Cap Go Meh Bogor Street Festival 
melakukan promosi pariwisata melalui akun @cgmbogor_fest dengan mengunggah poster digital, foto, video, dan potongan foto. Dari keempat bentuk promosi digital pada akun @ cgmbogor_fest, poster menjadi alat promosi utama karena dalam poster terdapat beberapa informasi, di antaranya tentang waktu dan tempat pelaksanaan festival, pengisi acara, nomor kontak yang dapat dihubungi serta media sosial yang dapat ditelusuri.

Penelitian lain yang masih memiliki fokus kajian dengan penulis ialah sebuah jurnal dari Gita Siswhara, dkk. (2017) dengan judul Pengaruh Promosi Melalui Instagram dan Event Terhadap Repurchase Intention Do Cenghar Kopi Kota. Penelitian ini berfokus pada pengaruh promosi melalui Instagram dan event terhadap repurchase intention di Cenghar Kopi Kota Cimahi. Berdasarkan penelitian yang dilakukan, didapatkan hasil yang menunjukkan bahwa promosi melalui Instagram dan event berpengaruh positif dan signifikan terhadap repurchase intention, baik secara parsial maupun simultan.

Kesadaran penggunaan Instagram sebagai media pengiklanan juga sudah digunakan oleh Festival Seni Yogyakarta (FKY) yang bertajuk "Rekreasi" sejak tahun 2013. Hal tersebut berdasarkan jurnal yang dibuat oleh Andrika Permatasari dengan judul Penggunaan Media Sosial sebagai Sarana Promosi Festival Kesenian Yogyakarta 2013. Penelitian tersebut menerangkan bahwa akun Instagram FKY (rekreasi) memiliki 77 unggahan dan 113 followers. Meskipun followers tidak sebanyak media sosial lainnya, pengguna Instagram yang mengunggah foto dan video mengenai FKY dengan hashtag \#fky25 mencapai 1.047 unggahan.

M. Fathurrahman, dkk. (2019) dalam jurnalnya yang berjudul Analisis Pesan Foto dan Teks Akun Instagram \#FOODFESTIVALBANDUNG dalam Mempromosikan Event Wisata Kuliner di Kota Bandung, mencoba menganalisis pesan foto dan teks untuk dapat melihat kategori mana yang paling sesuai untuk digunakan dalam sebuah event. Hasil dari penelitian tersebut ialah setiap kategori sudah memenuhi kriteria seperti penggunaan caption yang mudah dipahami, penggunaan hashtag yang memudahkan konsumen untuk mencari informasi mengenai event ini, dan adanya timbal balik atau feedback dilihat dari comment para konsumen pada unggahan kegiatan tersebut. Kategori yang paling sesuai adalah kategori video dibandingkan dengan sembilan kategori lainnya.

Berdasarkan pemaparan tersebut dapat dilihat relevansi penelitian sebelumnya dengan penelitian penulis ialah terletak pada fokus penelitian yang sama-sama berkaitan dengan pengiklanan sebuah festival menggunakan media sosial Instagram. Hanya saja yang menjadi penegas perbedaan dengan penelitian penulis ialah pada metode penelitian. Penelitian tersebut menggunakan metode kuantitatif, sementara penelitian yang penulis lakukan menggunakan metode kualitatif. 


\section{METODE}

Penelitian ini menggunakan metode kualitatif dengan pendekatan deskriptif. Studi deskriptif adalah sebuah penelitian yang berusaha mengungkap fakta suatu kejadian objek atau aktivitas, proses, dan manusia secara apa adanya, baik pada waktu sekarang maupun jangka waktu yang masih memungkinkan dalam ingatan narasumber (Andi, 2011, hlm. 203). Penulis menggunakan metode deskriptif kualitatif karena metode ini sangat sesuai untuk mendeskripsikan berbagai kondisi dan situasi objek penelitian. Metode ini juga sangat sesuai sebagai cara untuk menarik temuan penelitian ke permukaan sebagai suatu ciri, karakter, sifat, model atau gambaran tentang kondisi dan situasi permasalahan penelitian. Penelitian ini dilakukan di Sekretariat Rumah Karya Indonesia, Jalan Sisingamaraja No. 132, Medan, Sumatra Utara sebagai lokasi pelaksanaan sekretariat penyelenggara Tao Silalahi Arts Festival dan selaku admin dari akun Instagram@taosilalahiartsfest.

Subjek penelitian ini diambil menggunakan metode purposive sampling yaitu dengan cara menetapkan informan dengan berdasarkan kriteria-kriteria tertentu berdasarkan informasi yang dibutuhkan (Sugiono, 2016). Informan dalam penelitian ini selanjutnya akan dibagi menjadi dua kelompok, yaitu informan utama dan informan tambahan. Teknik pengumpulan data dilakukan dengan empat macam cara yang terdiri dari wawancara, observasi, dokumentasi, dan studi pustaka. Miles dan Huberman (1992: 16) berpendapat bahwa aktivitas dalam analisis data kualitatif dilakukan secara interaktif dan berlangsung secara terus-menerus sampai tuntas, sehingga data yang dibutuhkan terpenuhi. Penelitian ini menggunakan analisis data dengan istilah interactive model, teknik ini terdiri dari tiga komponen yaitu reduksi data, penyajian data, dan penarikan kesimpulan.

\section{HASIL DAN PEMBAHASAN}

\section{Bentuk Pengiklanan TSAF 2018-2019 melalui Media Instagram}

Berkowitz (1986, hlm. 459) menyatakan bahwa pada hakikatnya periklanan dapat dilakukan dengan berbagai tujuan yang berbeda, namun tetap didasari oleh dua tipe subjeknya, yaitu produk dan institusional. Iklan produk lebih berfokus pada penjualan barang dan jasa, sementara iklan jenis institusional lebih mengarah sasarannya pada pemberian jasa baik (goodwill) atau gambaran suatu organisasi. Dua bentuk iklan tersebut ditemukan dalam konten-konten yang diunggah oleh akun Instagram TSAF. Iklan yang berjeniskan produk, oleh Berkowitz (1986, hlm. 459) dibagi menjadi tiga tipe yang berupa perintisan (pioneering), persaingan (competitive), dan penguatan (reminder). Berdasarkan 
data yang sudah dipaparkan sebelumnya, ditemukan 85 konten yang bertipekan perintisan (pioneering) dan 26 konten yang bertipekan penguatan (reminder) dalam pengiklanan TSAF 2018-2019 melalui media Instagram. Bentuk iklan perintisan (pioneering) oleh Berkowitz (1986, hlm. 460) dijelaskan bahwa biasanya digunakan untuk memperkenalkan produk dengan kunci utamanya ialah memberikan target pasar secara informatif. Iklan yang bersifat informatif demikian ditemukan untuk menarik perhatian, meyakinkan, di mana efektivitasnya tergantung pada kosumen.

Dalam penyebarannya di akun media TSAF, tipe ini tersebar dalam tiga format konten yang berupa desain poster, foto, dan video. Ketiganya menyampaikan informasi secara mendetail yang berkaitan dengan informasi umum kegiatan, bentuk kegiatan, cara mendaftar, batas pendaftaran, penampil, penjualan, dan merchandise. Format konten berupa foto, memanfaatkan caption untuk menyampaikan pesannya. Maka dari itu, bentuk pengiklanan dalam tipe ini lebih cenderung memiliki caption yang panjang dengan bahasa yang informatif.

Pengiklanan produk yang bertipekan penguatan (reminder), digunakan saat kegiatan TSAF akan kembali dimulai setiap tahunnya, menuju kegiatan, kegiatan berlangsung, dan selesai kegiatan. Tipe ini memang tidak sebanyak dengan tipe perintisan karena sifatnya yang hanya menguatkan. Berdasarkan data yang ditemukan, beberapa konten berformatkan video yang berisikan after movie penyelenggaraan kegiatan sebelumnya. Hal ini digunakan untuk memberikan gambaran kepada audiens bagaimana keberlangsungan kegiatan yang akan dilaksanakan. Selain itu, ditemukan juga konten berformatkan foto yang berisikan keberlangsungan kegiatan. Konten tersebut akan memberikan informasi terbaru mengenai keberlangsungan kegiatan, sehingga memberikan penguatan terhadap konten-konten sebelumnya. Tipe iklan ini oleh Berkowitz (1986, hlm. 461) difungsikan untuk memperkuat pengetahuan sebelumnya akan suatu produk.

Sementara itu, jenis iklan produk persaingan (competitive) tidak ditemukan dalam akun Instagram TSAF. Hal yang ditemukan justru sebaliknya, TSAF mendapatkan dukungan dari festival lain. Hal tersebut seperti yang termuat dalam Tabel 2 nomor 11 mengenai dukungan dari Direktur Pasa Harau terhadap TSAF. Dukungan festival lain ini termasuk ke dalam jenis institusional yang mana lebih mengutamakan jasa baik (goodwill). Jenis tersebut oleh Berkowitz (1986, hlm. 462) dibagi lagi ke dalam tiga tipe, yaitu advocacy (pembelaan), pioneering institutional, dan competitive institutional. Lebih tepatnya hal tersebut terkategorikan dalam tipe advocacy (pembelaan) karena secara tidak langsung menunjukkan posisi perusahaan, dalam konteks ini memberikan kesan baik dengan cara mendapatkan dukungan dari festival yang lain. Iklan bertipekan advocacy (pembelaan) tersebut ditemukan sebanyak 22 buah dalam pengiklanan TSAF 2018-2019 melalui Instagram. 
Selain dalam bentuk dukungan, tipe ini juga ditemukan dalam konten yang bertemakan kampanye isu lingkungan. Hal tersebut dapat dilihat pada Tabel 1 nomor 28-39, 52-54, dan Tabel 2 nomer 9. Kampanye-kampanye seperti membersihkan danau dari sampah dan menanam pohon ini dilakukan oleh TSAF untuk menjaga aset yang dikembangkannya sekaligus sebagai turunan dari penggunaan tagline. Iklan pembelaan (advocacy) ini oleh Berkowitz (1986, hlm. 463) dijelaskan untuk memberitahukan posisi perusahaan dalam suatu persoalan.

Adapun ditemukan tipe iklan institusional yang bertipe pioneering institutional ditemukan dalam pengiklanan TSAF 2018-2019 melalui Instagram sebanyak delapan buah. Iklan bertipekan ini lebih bersifat informatif dan ingin mencari kesan baik dengan cara yang lebih halus. Hal tersebut salah satunya dapat dilihat dalam Tabel 2 nomor 39. Konten tersebut menunjukkan adanya kolaborasi dari seniman yang tergabung dalam Begawai Nusantara. Begawai Nusantara sebagai platform yang menaungi berbagai festival berbasis masyarakat di Indonesia menjadi hal penting untuk mendudukkan posisi TSAF.

Melalui dua jenis bentuk pengiklanan tersebut, TSAF memiliki keseimbangan dalam mencitrakan dirinya melalui Instagram, antara konten yang sifatnya produk dan konten yang bersifat komunitas. Hal tersebut oleh Sugiarto (2018: 31) disebut sebagai akun yang ideal. Hal ini akan membuat akun TSAF memiliki daya ungkit dan kepercayaan yang tinggi dari pengikutnya.

\section{Strategi Pengiklanan TSAF 2018-2019 melalui Instagram}

Hal-hal yang perlu diperhatikan dalam strategi pengiklanan ialah mengenai perencanaan. Adanya perencanaan yang tepat akan meminimalisasi terjadinya suatu kegagalan. David (2011, hlm. 283) menerangkan bahwa tahapantahapan strategi terdiri dari tiga tahapan yaitu perumusan strategi (perencanaan), pelaksanaan strategi, dan evaluasi strategi. Perumusan strategi TSAF 2018-2019 dimulai dari menerjemahkan tagline, mengidentifikasi pangsa pasar, membuat program pengiklanan, penentuan waktu unggah, dan pemanfaatan fitur.

TSAF memiliki tagline yang tetap setiap tahunnya yaitu Menenun Hijau Perbukitan, Merawat Kearifan Lokal. Tagline ini yang kemudian didiskusikan oleh Tim Publikasi TSAF 2018-2019 sebagai dasar pengambilan langkah berikutnya, karena tagline tersebut merupakan ekstrasi dari visi dan misi TSAF yang fokus kegiatannya pada kegiatan yang bernuansa alam dan kearifan lokal. Langkah berikutnya yang dilakukan tim publikasi ialah menentukan pangsa pasar. Pangsa pasar yang dipilih ialah anak muda rentang usia 16-35 tahun. Hal tersebut dipertimbangkan berdasarkan hobi yaitu travellers dan campers' yang kebanyakan adalah anak muda. Dalam hal ini pemilihan Instagram sebagai media pengiklanan menjadi hal yang tepat. Hal tersebut sesuai dengan hasil survei yang dilakukan oleh Napoleon Cat, bahwa sebagian besar pengguna Instagram di Indonesia didominasi oleh usia produktif, yakni pada rentang 16-34 tahun. 
Dominasi tersebut hingga 25 juta pengguna atau mendominasi 36-38\% (usia 1824 tahun) dan 21 juta pengguna (31-33\%) di rentang usia 25-34 tahun. Angka ini cukup besar apabila melihat seluruh pengguna Instagram di Indonesia hingga Mei 2020 tercatat 69,2 juta pengguna (goodnewsfromindonesia.id).

Setelah hal tersebut dipenuhi, persiapan lain Tim Publikasi TSAF ialah membuat program pengiklanan. Program tersebut meliputi give away dan promosi, kerja sama dengan influencer, serta kampanye isu lingkungan. Program give away dan promosi oleh Sugiarto (2018, hlm. 156) dijelaskan dapat untuk mengaktifkan followers pasif, mengajak follower baru, memperkenalkan produk, melihat kematangan komunitas di akun Instagram, dan yang paling penting ialah untuk mengapresiasi follower. Hal ini menjadi perencanaan yang penting, karena selain membuat follower lebih interaktif, juga dapat digunakan untuk menentukan langkah berikutnya.

Program berikutnya ialah mengajak influencer. Influencer sendiri merupakan orang yang berpengaruh atau dalam istilah Kotler (2012, hlm. 117) sebagai peran pendukung yang dapat menjaring perhatian dan recall yang lebih tinggi. Dalam konteks ini, indikator pemilihan influencer TSAF ialah pada personal yang memiliki hobi bepergian (traveller) dan memiliki jumlah follower yang banyak serta memiliki visi misi yang sama. Selain hal tersebut dapat juga orang-orang yang memiliki pengaruh dalam suatu kebijakan tertentu. Sementara itu program kampanye isu lingkungan merupakan representasi dari tagline yang telah dirumuskan. Program ini dikhususkan oleh TSAF sebagai konten positif yang memberikan kesadaran pada masyarakat. Melalui hal ini TSAF mengharapkan dapat memberikan perubahan akan pentingnya keseimbangan lingkungan.

Persiapan selanjutnya ialah menentukan waktu unggah. Waktu unggah menjadi salah satu piranti penting bagaimana konten dapat terjangkau dengan optimal. Penentuan waktu unggah ini oleh Sugiarto (2018, hlm. 93) dapat dilakukan dengan memperhatikan tiga hal, yaitu dengan cara menentukan jam berdasarkan asumsi, melihat data jam follower aktif, dan menyesuaikan jadwal secara terus-menerus.

Persiapan terakhir yaitu menganalisis fitur-fitur yang tersedia di Instagram. Fitur-fitur tersebut berupa hashtag (\#), caption, lokasi, dan mention. Hashtag sendiri menurut Sugiarto (2018, hlm. 81) merupakan fitur yang penting untuk digunakan, karena melalui hal ini dapat memberikan keuntungan konten dapat lebih mudah ditemukan, kesempatan masuk ke top post, dan memberikan gambaran algoritma kategori konten yang akan ditayangkan. Maka dari itu, pemilihan hashtag juga membutuhkan kejelian supaya konten yang diunggah dapat terpublikasi secara optimal. Pencarian hashtag sendiri dapat dilakukan dengan cara menentukan dua hashtag yang unik yang digunakan untuk bisnis sendiri dan mencari hashtag sebagai pendukung dengan minimum pengguna 500, 
bertahap, hingga sampai ke 500.000 (Sugiarto, 2018, hlm. 89). Langkah-langkah perumusan strategi tersebut merupakan penjabaran dari konsep perumusan strategi David (2011, hlm. 283) yang mencangkup pengembangan visi misi, pengidentifikasian peluang eksternal organisasi dan ancaman, penentuan kekuatan dan kelemahan internal, penetapan tujuan jangka panjang, menghasilkan strategi alternatif, dan memilih strategi tertentu untuk mencapai tujuan.

Setelah tahap perumusan strategi selesai, tahap berikutnya yang dilakukan ialah tahap pelaksanaan. Tahap ini menurut David (2011, hlm. 283) merupakan tahap untuk mengalokasikan sumber daya sehingga strategi yang dirumuskan dapat dilaksanakan. Menurutnya, dalam tahap ini juga diperlukan kebijakankebijakan pengambil keputusan. Tim publikasi TSAF sendiri terdiri dari desain visual, editor video, fotografer, dan admin. Di mana semua itu di bawah komando dari koordinator publikasi. Dalam tahap ini, penerjemahan tagline dan pangsa pasar mewujud dalam desain yang berformatkan video, foto, dan desain poster.

Desain TSAF sendiri cenderung menggunakan warna hijau dan biru serta font berjenis Sans Serif yang berwarna putih. Hijau dan biru menjadi warna dasar yang tidak diubah. Hanya saja pada penyelenggaraan TSAF 2019 ada sedikit perbedaan background yang digunakan berwarna putih. Dalam layouting sebuah desain periklanan, Suhandang (2016, hlm. 104) menyarankan untuk mempertimbangkan tiga hal yaitu headline, lead, dan body. Menurutnya susunan tersebut tidak harus seperti berita yang selalu berurutan melainkan tergantung dari komponen ataupun gaya yang akan ditonjolkan. Gaya desain yang digunakan TSAF cenderung menggunakan gaya unbalance make-up yang mana oleh Suhandang (2016, hlm. 105) disebut sebagai penataan yang seimbang namun tidak simetris. Hal tersebut dapat dilihat dari konten desain poster yang disajikan.

Desain-desain yang disajikan di tahun 2019 sudah memiliki komposisi yang seimbang daripada desain-desain yang ditampilkan di tahun 2018. Komposisi yang dimaksud ialah pemilahan hal-hal yang perlu diletakkan pada slide tersendiri, dalam hal ini ialah bagian sponsorship yang terlalu kecil dan berkerumun, sehingga menimbulkan kesan sesak dan penuh. Hal tersebut dapat disiasati dengan penggunaan feed yang carousel. TSAF sendiri memiliki keunggulan dalam pengunggahan foto dan video, karena kebanyakan konten yang diunggah berkaitan dengan landscape alam dan budaya sekitar yang berkualitas tinggi sehingga apa yang disajikan menarik dan memberikan gambaran yang lebih nyata. Hal tersebut sejalan dengan pendapat Sugiarto (2016, hlm. 63) bahwa gambar yang berkualitas tinggi akan memberikan daya tarik yang lebih tinggi.

Program pengiklanan TSAF 2018-2019 yang direncanakan juga terlaksana. Program give away terlaksana sebanyak dua kali yaitu pada tanggal 19 dan 25 Juli 2019. Sementara promo hanya dilakukan sebanyak satu kali yang dilaksanakan pada tanggal 25 Juli 2019 dengan materi memberikan gelang gratis 
kepada 100 pendaftar pertama. Sementara kerja sama dengan influencer melibatkan @ siparjalang dengan pengikut sebanyak 17,4 ribu, Bupati Kabupaten Dairi, dan Zul Nofri selaku Direktur Festival Pasar Harau (@pasarharau) yang membuat video dukungan terhadap kegiatan TSAF 2019. Influencer tersebut dalam istilah Kotler (2012, hlm. 117) dijelaskan sebagai peran pendukung yang dapat menjaring perhatian dan recall yang lebih tinggi. Dalam konteks ini, masing-masing influencer tersebut memiliki peran tersendiri, seperti @ siparjalang misalnya, dengan background-nya sebagai traveller memiliki jumlah follower yang banyak dapat memberikan pengaruh pada para followernya. Berdasarkan konten yang diunggah, konten tersebut mendapatkan 2.247 like dan 64 komentar. Dalam hal ini @ siparjalang dapat mencuri perhatian lebih dari 13\% pengikutnya. Bupati Dairi berfungsi untuk lebih meyakinkan pada publik bahwa acara tersebut juga mendapat dukungan dari pemangku kebijakan setempat sehingga masyarakat yang ingin hadir akan lebih percaya dan merasa aman. Sementara itu Zul Nofri selaku Direktur Festival Pasar Harau berfungsi untuk menyebarkan informasi kepada publik yang lebih luas dan menunjukkan luasnya jejaring TSAF.

Berdasarkan data yang sudah dipaparkan pada sub-bab sebelumnya, frekuensi unggahan TSAF 2018 berjumlah 86 unggahan. Jumlah tersebut terbagi dari bulan Maret (6), April (2), Mei (22) Juni (39), dan Juli (17). TSAF 2018 sendiri terselenggara pada 20-22 Juli 2018 yang artinya TSAF 2018 sudah memulai mengiklankan kegiatannya sejak empat bulan sebelum kegiatannya berlangsung. Frekuensi tersebut belum merata, bahkan terdapat beberapa unggahan yang lebih dari tiga kali pada setiap harinya yaitu pada 28 Mei (9), 1 Juni (6), dan 16 Juni (12). Sugiarto (2016, hlm. 75) menjelaskan bahwa jumlah unggahan per hari minimal satu dan maksimal tiga unggahan, karena apabila lebih dari jumlah tersebut akan menjadi spamming konten. Dapat dikatakan dalam pengiklanan TSAF 2018 belum memiliki jumlah unggahan yang konsisten setiap harinya.

Berbeda dari tahun sebelumnya, pengiklanan TSAF 2019 lebih memiliki batasan dalam jumlah unggah. Semenjak Februari-September 2019 terhitung sebanyak 85 kali unggahan yang diunggah oleh TSAF. Jumlah tersebut tersebar dari Februari (3), Maret (4), April (2), Juli (17), Agustus (29), dan September (19). Adapun bulan yang tidak memiliki unggahan dalam rentang tersebut ialah pada bulan Mei dan Juni. Jumlah yang diunggah minimal satu dan maksimal tiga unggahan setiap harinya.

Pemanfaatan fitur yang ada di Instagram sudah digunakan oleh TSAF. Fitur-fitur tersebut antara lain ialah hashtag (\#), caption, lokasi, dan mention. Fitur hashtag yang digunakan oleh TSAF ialah \#100tenda, \#rumahkaryaindonesia, telah digunakan lebih dari lima ribu unggahan, \#taosilalahiartfestifal digunakan lebih dari seribu unggahan, dan \#paropo telah 
digunakan lebih dari 28 ribu unggahan. Sugiarto (2018, hlm. 80) menjelaskan bahwa penggunaan hashtags akan membantu algoritma Instagram dalam mengategorikan konten. Dengan begitu pengguna akan lebih mudah mencari ataupun menandai foto yang mereka unggah. Penggunaan hashtag ini juga akan membantu branding TSAF, hal tersebut terbukti dari salah satu hashtag yang digunakan oleh TSAF telah digunakan lebih dari 28 ribu unggahan.

Fitur caption dalam pengiklanan TSAF berfungsi untuk menambahkan penjelasan terkait hal-hal yang belum terkomunikasikan melalui visual. Berdasarkan data yang diperoleh, ada perbedaan gaya mengenai caption yang digunakan oleh TSAF 2018 dan 2019. Caption TSAF 2018 banyak menggunakan huruf kapital untuk menegaskan hal-hal yang ingin dijelaskan dan terkesan masih kaku, sedangkan caption yang digunakan oleh TSAF 2019 lebih komunikatif dengan gaya bahasa yang santai. Huruf kapital hanya digunakan di awal kata pada headline dan di awal kalimat.

Fitur lokasi juga digunakan dalam beberapa unggahan TSAF. Lokasi yang digunakan antara lain ialah Tao Silalahi, Silalahi Nabolak-Hutani Raja Silalahi Sabungan, dan Paropo-Sumatra Utara-Indonesia. Penandaan lokasi ini menurut Sugiarto (2016, hlm. 91) akan memudahkan pengguna lain untuk mencari lokasi yang ingin dituju. TSAF pun menggunakan mention (@) untuk menandai akun yang lain untuk menunjukkan akun yang terkait dengan informasi yang disampaikan oleh TSAF.

Tahapan terakhir yang dilakukan dalam konsep David (2011, hlm. 283) ialah evaluasi strategi sebagai alat utama memperoleh informasi. Hal tersebut dapat dilakukan dengan penilaian yaitu meninjau ulang faktor eksternal dan internal yang menjadi landasan bagi strategi saat ini, pengukuran kinerja, serta pengambilan langkah korektif. Berdasarkan data yang sudah dipaparkan sebelumnya, strategi pengiklanan TSAF 2018-2019 dapat dikatakan berhasil apabila dilihat dari capaian pengunjung yang menghadiri kegiatan tersebut. Akan tetapi, perlu adanya upaya untuk menyinergikan antara persiapan yang direncanakan dengan pelaksanaannya karena pemilihan Instagram sebagai media pengiklanan sudah sesuai dengan pangsa pasar audiens yang dipilih. Selain itu, TSAF juga memiliki kekuatan yang cukup besar sebagai modal untuk dapat mengoptimalkan pengiklanannya melalui Instagram.

Gambaran mengenai kegiatan, lokasi, serta kearifan budaya lokal sudah tercitrakan dengan baik melalui foto dan video yang berkualitas tinggi. TSAF juga memiliki kerja sama yang baik dengan para influencer karena memiliki visi dan misi yang sama. Selain itu, TSAF memiliki follower yang dikelola secara organik sehingga memungkinkan untuk berinteraksi secara mendalam. Kekuatan lain yang tidak bisa dikesampingkan ialah pengalaman TSAF yang menyelenggarakan kegiatannya lebih dari dua kali. Hal tersebut menjadi bukti paling konkret untuk menarik perhatian publik. Akan tetapi, adanya kekuatan 
tersebut perlu diimbangi dengan perbaikan beberapa hal yang memengaruhi optimasi pengiklanan di Instagram seperti konsistensi jumlah unggah, meningkatkan jumlah follower, dan mencoba menggunakan iklan berbayar supaya dapat menjangkau publik yang lebih luas. Karena melihat peluang dan kekuatan yang dimiliki oleh TSAF, memungkinkan pengiklanan tersebut untuk dapat lebih ditingkatkan.

Berdasarkan pemaparan yang telah disampaikan, bahwa bentuk pengiklanan TSAF 2018-2019 melalui Instagram menggunakan bentuk pengiklanan berjenis produk dan institusional. Iklan jenis produk bertipekan perintisan (pioneering) yang digunakan untuk menyampaikan informasi secara mendetail dan penguatan (reminder) yang digunakan untuk menguatkan hal-hal sebelumnya yang pernah dilakukan. Sementara iklan berjeniskan institusional bertipekan pembelaan (advocacy) yang digunakan untuk mendudukkan keberpihakan TSAF dalam suatu persoalan dan pioneering institutional yang digunakan untuk menginformasikan sesuatu secara rinci akan tetapi lebih mengarah kepada jasa baik.

Strategi pengiklanan TSAF 2018-2019 terdiri dari tiga tahap yaitu berupa perumusan strategi, pelaksanaan strategi, dan evaluasi strategi. Pada tahap perumusan, TSAF memulainya dengan penerjemahan tagline, penentuan pangsa pasar, perumusan program, riset waktu unggah, dan pemanfaatan fitur. Dalam pelaksanaannya, desain TSAF 2018-2019 menggunakan gaya unbalance makeup sebagai penataan yang seimbang namun tidak simetris. Program give away dan promosi, kerja sama dengan influencer, dan kampanye isu lingkungan dapat terlaksana dengan respons yang baik. Pemanfaatan fitur seperti hashtag (\#), caption, lokasi, dan mention sudah difungsikan dengan tepat. Berdasarkan evaluasi yang dilakukan, strategi pengiklanan TSAF 2018-2019 dapat dikatakan berhasil dengan adanya peningkatan pengunjung. Akan tetapi perlu adanya upaya untuk menyinergikan antara persiapan yang direncanakan dengan pelaksanaannya.

\section{KESIMPULAN}

Berdasarkan analisis yang telah dilakukan pada penelitian yang berjudul Pengiklanan Tao Silalahi Arts Festival 2018-2019 melalui Media Sosial Instagram dapat disimpulkan bahwa, pertama, bentuk pengiklanan TSAF 20182019 melalui Instagram menggunakan bentuk pengiklanan berjenis produk dan institusional. Iklan jenis produk bertipekan perintisan (pioneering) yang digunakan untuk menyampaikan informasi secara mendetail dan penguatan (reminder) yang digunakan untuk menguatkan hal-hal sebelumnya yang pernah dilakukan. Sementara iklan berjenis institusional bertipekan pembelaan (advocacy) yang digunakan untuk mendudukkan keberpihakan TSAF dalam 
suatu persoalan dan pioneering institutional yang digunakan untuk menginformasikan sesuatu secara rinci akan tetapi lebih mengarah kepada jasa baik.

Kedua, strategi pengiklanan TSAF 2018-2019 terdiri dari tiga tahap yaitu berupa perumusan strategi, pelaksanaan strategi, dan evaluasi strategi. Pada tahap perumusan, TSAF memulainya dengan penerjemahan tagline, penentuan pangsa pasar, perumusan program, riset waktu unggah, dan pemanfaatan fitur. Dalam pelaksanaannya, desain TSAF 2018-2019 menggunakan gaya unbalance makeup sebagai penataan yang seimbang namun tidak simetris. Program give away dan promosi, kerja sama dengan influencer, dan kampanye isu lingkungan dapat terlaksana dengan respons yang baik. Pemanfaatan fitur seperti hashtag (\#), caption, lokasi, dan mention sudah difungsikan dengan tepat. Berdasarkan evaluasi yang dilakukan, strategi pengiklanan TSAF 2018-2019 dapat dikatakan berhasil dengan adanya peningkatan pengunjung, akan tetapi perlu adanya upaya untuk menyinergikan antara persiapan yang direncanakan dengan pelaksanaannya.

\section{KEPUSTAKAAN}

Berkowitz, T. Darwin. (1992). Marketing. Toronto: Times Mirror/Mosby College Publishing.

David, Fred R. (2011). Strategic Konsep, Edisi 12. Jakarta: Salemba Empat.

Fathurrahman, M. dkk. (2019). Analisis Pesan Foto dan Teks Akun Instagram \#FOODFESTIVALBANDUNG dalam Mempromosikan Event Wisata Kuliner di Kota Bandung. e-Proceeding of Management, 6 (3) 1-9.

Imam, Mustofa. (2020, Juni). Pengguna Instagram di Indonesia Didominasi Wanita dan Generasi Milenial. Diambil dari https://www.goodnewsfromindonesia.id/2020/06/14/pengguna-Instagram-di-indonesiadidominasi wanita-dan-generasi-milenial

Kasmir. Bank dan Lembaga Keuangan Lainnya. Jakarta: PT. Raja Grafindo Persada.

Kotler, P. dan Keller, K.L. (2012). Manajemen Pemasaran, Jilid I Edisi 12. Jakarta: Erlangga.

Noor, Any. (2013). Management Event. Bandung: Alfabeta.

Permatasari, Andrika. (2015). Penggunaan Media Sosial sebagai Sarana Promosi Festival Kesenian Yogyakarta 2013. Narada, Jurnal Desain dan Seni, 2 (1), 67-75.

Pratiwi, Aprilianti dan Madanacaragni, M. Girindra. (2020). Instagram sebagai Media Promosi Festival Pariwisata Kota Bogor (Studi Etnografi Virtual Pada Akun@Cgmbogor_Fest).Jurnal Audience: Jurnal Ilmu Komunikasi, 3 (1), 117-145.

Pudjiastuti, Wahyuni. (2010). Special Event. Jakarta: PT. Elex Media Komputindo. 
Riyanto, Andi Dwi. (2020). Hootsuite (We are Social): Indonesian Digital Report 2020. Diambil dari https://andi.link/hootsuite-we-are-socialindonesiandigital-report-2020.

Saebani, Beni Ahmad. 2013. Metodologi Penelitian Kualitatif. Bandung: Pustaka Setia.

Siswhara, Gita, dkk. (2017). Pengaruh Promosi Melalui Instagram dan Event Terhadap Repurchase Intention Do Cenghar Kopi Kota. Gastronomy Tourism, 3 (2), 19-26.

Shimp, Terence. (2003). Periklanan Promosi. Jakarta: Erlangga.

Suhandang, Kustadi. (2016). Manajemen, Kiat, dan Strategi Periklanan. Bandung: Penerbit Nuansa.

Sugiarto, Matthew. (2018). Instagram Marketing. Jakarta: PLP Book.

Sugiyono. (2016). Metode Penelitian Kuantitatif, Kualitatif dan R\&D. Bandung: Alfabeta. 